Gramáticas de la (¿post?) violencia:

identidades, guerras, cuerpos y fronteras

\title{
'Scientific torture'? \\ Scientism and the marks of torture inside a police station in Belo Horizonte, Brazil
}

\author{
Pedro Fermín Maguire ${ }^{7}$ \\ Denise Neves Batista Costa ${ }^{1}$ \\ - Universidade Federal de Minas Gerais, \\ Programa de Pós-graduação em Antropologia, Belo Horizonte/MG, Brasil
}

\begin{abstract}
The aim of this article is to examine several architectural marks registered during 2013-2015 at the police station that once housed the DOPS, the headquarters of Brazil's dictatorial police in the city of Belo Horizonte. To understand their importance as archaeological findings, we propose an analysis of 'scientific torture'. We will examine the phrase's genealogy and the practices associated with it in the second half of the twentieth century. While practiced by a number of institutions from several countries, it was the CIA that created an entire research program to organize bodies of knowledge about torture practices, producing now declassified documents about 'interrogation techniques'. First, we will discuss some of the materialized practices developed as a result of those efforts. Second, we will discuss how these practices are reflected in the Kubark interrogation manual, edited by the CIA in 1963, particularly in what pertains to its more architectural recommendations. Finally, we will analyze the building which once housed the DOPS, to expose the notable congruencies between its architectural recommendations and the marks recorded at the DOPS building.
\end{abstract}

Key words: Torture, Archaeology of Repression, Interrogation, Internment, CIA. 


\section{Uma ciência da tortura? \\ Cientificismo e marcas de tortura numa delegacia de Belo Horizonte, Brasil}

\section{Resumo}

O objetivo deste artigo é examinar várias marcas de arquitetura registradas entre 2013-2015 na delegacia que um dia sediou o DOPS, o QG da polícia política na cidade de Belo Horizonte. Para compreender a importância destas marcas enquanto achados arqueológicos, propomos uma análise da 'tortura científica'. Exploraremos a genealogia do termo e as práticas associadas a ele na segunda metade do século vinte. Embora posta em prática por várias instituições de diferentes países, foi a CIA que criou todo um programa de pesquisas para organizar corpos de conhecimento sobre práticas de tortura, produzindo documentos sobre 'técnicas de interrogatório' agora desclassificados. Primeiro, discutiremos algumas das práticas materializadas desenvolvidas em decorrência desses esforços. Depois discutiremos como elas ficam refletidas pelo manual de interrogatórios Kubark, editado pela CIA em 1963, em particular no referente às suas recomendações arquitetônicas. Finalmente, analisaremos o prédio que um dia sediou o DOPS, para mostrar as chamativas correspondências entre as suas recomendações arquitetônicas e as marcas registradas no prédio do DOPS.

Palavras-chave: Tortura, Arqueologia da Repressão, Interrogatórios, Internamento, CIA. 


\title{
'Scientific torture'? Scientism and the marks of torture inside a police station in Belo Horizonte, Brazil
}

\author{
Pedro Fermín Maguire \\ Denise Neves Batista Costa
}

\section{Torture in Minas Gerais during the Brazilian dictatorship of 1964-1985}

The Brazilian military regime's recurrent use of torture against social and political activists, ranging from clergymen to guerrillas, is one of the period's key issues. Historians and other scholars have confirmed that other countries helped train Brazilian officials to perpetrate these heinous crimes, thereby confirming old suspicions. The political scientist Martins Filho has described how the US doctrine of 'National Security' - denounced by father Joseph Comblin (Martins Filho, 2008) - legitimized the regime's violent practices. While the prominent role played by the USA in coordinating dictatorial efforts through the School of the Americas has been highlighted, more recent investigations have documented the involvement of other countries. Investigative journalist Marie-Monique Robin's book and documentary Escadrons de la mort, l'école française reveals the role of French generals in Latin America. After fighting in the Algerian Revolution (1954-1962), French Army men seasoned in combating Algerian revolutionaries helped train the dictatorial armies of the 1970 in several Latin American countries, including Brazil, Argentina and Chile.

These studies outline the development of a global body of counter-insurgency theory and practice, structured around a series of interconnected training centers. What has emerged is the existence of an intricate network with regional and local diversities. Martins Filho (2017) recently published his investigation into the involvement of the British Army in the development of torture methods used in Rio de Janeiro. These 'interrogation techniques' were later used during the troubles in Northern Ireland, and included sensory deprivation, a central practice within the paradigm of 'scientific torture' that we will describe shortly. Denunciations of torture in the state of Minas Gerais, South-East Brazil, go back to 1970, when guerrilla fighter Ângelo Pezzuti described a Brazilian Lieutenant teaching a practical 'lesson in torture' inside the hall of the Army's First Company in Belo Horizonte, the state capital (Gaspari, 2009, p. 274). Controversies and allegations of torture also surrounded USAid employee Dan Mitrione's time in Belo Horizonte (Arns, Sobel \& Wright, 1985). Mitrione left the city for Montevideo in August of 1970, where he was kidnapped and assassinated by Uruguayan Tupamaro guerrillas shortly after arriving in the country. His death triggered investigations into the nature of his work as the Director of the US Program for Public Health in Brazil and Uruguay, which aimed to foster a "more responsible and humane police administration" (McCoy, 2005, p. 227), and which connected him to the Office of Public Safety. There were allegations that Mitrione was involved in training Latin American police and armed forces in the use of torture.

Although suspicions surrounding Mitrione elicited an official US Congress inquiry (more on which below), Minas Gerais historian Rodrigo Patto Sá’s (2010) documentary research concluded that it was 'unlikely' that the state's police were trained by him. Patto Sá reminds us that Mitrione was in Belo Horizonte some years before the peak of political repression and that 'the Brazilian police already had 
long experience in the field' (Patto Sá, 2010, p. 246). Police abuse had been denounced by the press even before the 1964 coup and ensuing dictatorship. In criticizing the simplistic and somewhat scapegoating image of 'Brazilians being taught to torture' by US officials, Patto Sá (2010) traces the roots of US-Brazilian collaboration to the 1950s, when civil and military authorities from both countries exchanged knowledge and technology in an effort to 'modernize' Brazilian public safety. It was during that time that the Belo Horizonte police station that we will analyze in this article was built.

Patto Sá describes most Brazilian authorities as reticent towards the idea of being 'taught' by their US counterparts. Brazilians were more interested in certain technological devices than in teachers. According to Patto Sá, the Brazilian police are more likely to have imported portable radios, which enabled electric shocks to be administered in different rooms inside a building. Like most social studies of technology, Patto Sá's analysis stresses more localized efforts to understand the use of torture techniques, taking us beyond the idea of mere 'adoption' and 'modernization'.

\section{Why a building matters}

Faced with such a complex pattern, we discuss the 'interrogation techniques' used in one particular building, approaching them as technical practices that are better understood as technological choices rather than as mere 'modernized imports'. A study in historical archaeology (sensu Funari, Hall and Jones, 1999), this article uses a heterogeneous set of local materials, from written sources to building maps, from manuals to interviews. We will make use of the impressive dossier edited by Françoise Jean de Oliveira Souza and Teodoro Magni (2015), which conferred Cultural Heritage status on the police station on Av. Afonso Pena 2351, in Belo Horizonte. Built in 1958, at the height of the 'modernizing' efforts of US and Brazilian cooperation, the police station once housed the headquarters of the Departamento de Ordem Politica e Social (literally, The Department of Political and Social Order). As we will see, this police station became a key center of intelligence and interrogation in the State of Minas Gerais during the 1964-1985 dictatorship. The dossier includes pictures, layout maps and excerpts from interviews carried out in 2013 and published in 2015, and also documents from the Public Archive of the State of Minas Gerais (Arquivo Público Mineiro).

To assess the importance of this material, we will analyze the theory and practice of 'scientific' or 'psychological torture'. First, we will approach it as a body of knowledge developed under the financial support and auspices of Cold Warriors worldwide, by tracing the history of the CIA's efforts to 'improve interrogation techniques'. Second, we will analyze the ideas and architectural implications of this peculiar body of knowledge, beginning with a 1963 secret CIA interrogation manual, the Kubark manual. This is a handbook for the dubious field of so-called 'scientific torture' or 'psychological torture', and it is filled with references to and recommendations about sensory deprivation. In light of its contents, we propose an archaeological interpretation of the architectural layout and marks found inside the DOPS building by the authors of the dossier. The result is a local, testimony-based analysis of the uses of the building and of the material traces of the practice of torture.

Torture centers and illegal detention centers were an integral part of the repressive structures of the Brazilian military regime, operating under the command of the Armed Forces. They were places where political opponents were imprisoned and interrogated, and they bear the traces of these practices. We understand torture to be the:

(...) adoption of measures which restrict a detained person's freedom beyond the level of suffering which is strictly necessary and intrinsic to detention, such as: the imposition of isolation in reduced cells, without ventilation or natural light; the restriction of visiting hours; intimidation and threat of violent acts; physical violence against the 
victim; the prisoner's nude exposure or use of humiliating clothes; lack of access to basic services, such as medical attention, food and hygiene. It is also considered torture to expose the prisoner to protracted isolation and to hold the prisoner incommunicado coercively (National Truth Commission, 2014 apud Costa, 2017, p. 42).

Like prisons and concentration camps, illegal detention and torture centers were instrumental in enabling repressive forces to inhibit contact between those individuals categorized as 'criminals' and wider society. However, unlike prisons and concentration camps, illegal detention centers secure the complete isolation of individuals. Furthermore, illegal detention centers are harder to recognize from the outside, and they are usually set up inside pre-existing buildings which are adapted to become centers of torture (Salerno \& Zarankin, in Myers \& Moshenska, 2011). Archaeology can contribute to an understanding of strategies of repression by the dictatorial regime and of resistance by groups involved in political struggles (González Ruibal, 2011), tracing back their identities and existences (Costa, 2017). On some very fortunate occasions, archaeologists can incorporate the testimonies produced by those very same threatened existences. The focus of these testimonies - and of all the materials used in this article - is the building once used as a center of torture. But we will use the accounts of survivors as a central aspect of the questions structuring this work: What was so-called 'scientific torture'? How far can it be distinguished from mere torture? What was the point of such a distinction? By placing survivors' insights at the heart of an understanding of 'spaces of violence', as proposed by Pamela Colombo $(2016,2017)$, we will explore yet another path that can connect oral sources to material culture in archaeology. As we will see, survivors' accounts provide an interesting counterpart to formalized bodies of knowledge about 'psychological' or 'scientific' torture.

\section{The CIA's research into scientific torture}

To adequately understand the importance of the architectural marks found inside the former DOPS building in Belo Horizonte, we must understand 'scientific torture'. Insofar as torture can have - or even be - a method, could it ever be considered 'scientific'? Historically, what conditions have enabled 'scientific' or 'psychological' forms of torture to emerge? Some of these questions are addressed by US historian Alfred McCoy's overview of torture and his fine-grained analysis of its development by the CIA in recent history (McCoy, 2005). Since the end of the Second World War, the CIA has been involved in funding research to develop torture practices which it disguised through the qualifiers 'psychological' and 'scientific' (McCoy, 2005). The type of torture that CIA officials and researchers called 'scientific' converge on the search for new methods and the use of discourses and places of political opacity. Places of internment (Myers \& Moshenska, 2011) like concentration camps (Gonzalez-Ruibal in Myers \& Moshenska, 2011), were places where states of emergency and exceptional powers caused buildings to be used and/or built for the monopolized use of force, delimiting a place where all restrictions and limitations of power over the human body were suspended.

McCoy identifies some of the precedents for 'scientific' torture in the experiments carried out in the Nazi camp of Dachau, and by the French Army in the Algerian Revolution. Invested with exceptional powers, the French Army turned to opaque and covert counter-insurgent tactics, inaugurating a new form of colonial warfare. In so doing, it applied a variety of methods, combining medieval drownings with more 'modern' electroshocks. As McCoy highlights, the CIA is an organization born under the exceptional powers of the US executive and, in the context of the Cold War, it was granted tremendous leeway, conferring upon it an 'extraordinary capacity to act outside the law.' (McCoy, 2005, p. 216) The CIA's experiments in the field of 'psychological' or 'scientific' torture began almost exactly where those of the Nazis had been abandoned. 
Through its predecessor, the Office of Strategic Studies (OSS), the CIA came to employ those in charge of the Dachau experiments and it continued to experiment with LSD and THC for the interrogation of spies and double agents.

The search for new techniques of interrogation was continued under the impact and spell of the Stalinist trials. In 1950, CIA reports closely scrutinized the public confessions of former Bolshevik leaders accused of political deviation. In 1951, after US soldiers detained during the Korean War publicly denounced their own country's imperialism on TV, the CIA began to fear possible developments in communist 'interrogation science'. Flabbergasted, CIA clinicians wrote that "the Communists are using drugs, physical pressure, electroshocks, and possibly hypnosis on their enemies" (McCoy, 2005, p. 216). Head CIA officials embarked on a technological race to match the developments in 'mind control' that they attributed to their communist counterparts. In 1950, in the context of an operation launched by CIA director Roscoe Hillenkoetter, and with the aid of polygraph experts and hypnotists, agent Boris Pash studied Nazi interrogation methods, including 'drugs, electroshocks, hypnosis and psycho-surgery' (McCoy, 2005, p. 217). The experiments were carried out in places where the Agency could make use of its institutional opacity and the limited mobility of persons deprived of their freedom, including those held in military facilities: first, Korean War prisoners; later soldiers detained at the Maryland Edgewood Chemical arsenal, or patients from the US drug-treatment centre in Lexington, Kentucky. During the two decades that followed, shielded from democratic controls and safe from public opinion, the Agency invested several millions of US taxpayer's money in research involving 185 non-governmental scientists, 44 universities, and 12 hospitals, in programs for 'mind control'. Between 1953 and 1963, project MKUltra - which gathered all previous research on 'mind control'- was placed under the supervision of Richard Helms, Assistant Deputy Director of Plans, which McCoy considers 'a euphemism for covert operations' (McCoy, 2005, p. 217). The project received 25 million dollars.

A second line of CIA studies on mind control focused on behavioral psychology and sensory deprivation. These experiments were carried out with British and Canadian institutions. Large funds were granted to Drs. Hebb and Cameron of McGill University in Canada. McGill psychologist Dr. Donald Hebb received a 10,00o-dollar grant from the Canadian Defense Research Board for his experiments in sensory isolation as psychological treatment, but the CIA's interest in 'mind control' ultimately prevailed. Dr. Hebb's studies are well-documented in Naomi Klein's The Shock Doctrine (2008). Despite his scientific insistence on the 'mental' nature of the control being sought, Hebb's behaviorist approach demanded the use of different artifacts and apparel which, literally, smothered individuals' bodies. Entire artefactual assemblages were used intrusively, asphyxiating those who were being experimented on. The subject-objects of his research were forced to use headphones, sometimes for three days in a row, their entire bodies covered in foam. Inside Dr. Hebb's lab, patients' mobility was severely restricted. Their everyday movements, which would have enabled them to establish relations with the outside world and the everyday landscapes that they would have encountered, were suddenly replaced by an entirely different and shackling assemblage. Through this apparel, 'the subject's very identity had begun to disintegrate' (McCoy,2005, p. 219).

In 1957, Dr. Hebb's research was further developed by Dr. Ewen Cameron, then president of the Canadian Psychatric Association. Dr. Cameron claimed to be able to "replicate the extraordinary political conversions of iron-curtain countries [using] sleep deprivation, uninhibiting agents and hypnosis" (McCoy, 2005, p. 219). Within the CIA-funded programme, through a "front institution" called the Sociey for the Investigation of Human Ecology (Klein, 2008, p. 35), Dr. Cameron began to take advantage of the good will of those who approached the laboratory, including students and people seeking jobs at his clinic. Over the 
six years that followed, some 100 Allan Memorial Institute patients were submitted to Dr. Cameron's treatment. Raising personality depatterning to the category of a paradigm, Dr. Cameron used psychiatry to explore the limits of freedom and control over the bodies of others.

Although the CIA's alleged intention was again to develop interrogation methods for 'mind control', under Dr. Cameron's direction the most drastic impact was directed towards human bodies. New technology was applied in cruelly imaginative ways:

'The two psychiatrists who invented the controversial Page-Russell electroshock machine had recommended four treatments per patient, totaling twenty-four individual shocks. Cameron started using the machine on his patients twice a day for thirty days, a terrifying 360 individual shocks to each patient'- (Klein, 2008, p. 35).

Technological changes brought about an important transformation in the interaction between doctor and patient, leading the building to act as an increasingly important mediator of Dr. Cameron's practice. Although, as we shall discuss below, one of Foucault's (1975) lessons about disciplinary architecture was that hospitals have always been characterized by a certain pattern which dates back to medieval monasteries (see also Markus, 1993 below), Dr. Cameron's practice required buildings to undergo further architectural adaptations to become suitable 'laboratories':

'When the CIA dollars arrived, Cameron used the grant money to convert the old horse stables behind the hospital into isolation boxes. He also elaborately renovated the basement so that it contained a room he called the Isolation Chamber. He soundproofed the room, piped in white noise, turned off the lights and put dark goggles and "rubber eardrums" on each patient, as well as cardboard tubing on the hands and arms, "preventing him from touching his body — thus interfering with his self-image," as Cameron put it in a 1956 paper' (Klein, 2008, p. 36).

These adaptations caused the buildings where Dr. Cameron worked to become more and more hostile - as Klein shows, they became increasingly similar to prisons. Dr. Cameron's practice also became increasingly militarized. Significantly, it was at the Texas Brook Air Base, before a military audience, that he claimed to have moved on from 'self-inflicted sensory deprivation' to 'strict sensory deprivation' with 'much more disturbing' results (McCoy, 2005, p. 220).

What can be made of the alleged scientific character of this medical practice? McCoy and Klein stress that, from a clinical perspective, it was basically counter-productive. After Cameron's experiments came to an end in 1967, the Allan Memorial Institute discovered that $60 \%$ of those patients who had undergone the full psychiatric program suffered severe consequences including amnesia, and $23 \%$ of them had physical complications. The CIA began defunding the project in 1963 and eventually dismantled it in 1973. Helms had become director of the CIA and wanted to avoid exposure.

At this time, the psychiatrists' experiments had restored what Latour considers to be one of the key contributions of modern science: certainty. Dr. Cameron had restored the Agency's belief that it could at least match what it had once considered to be the ground-breaking findings of the Soviets. McCoy quotes the conclusions of one of the Agency's psychologists:

'the general idea we have been able to understand is that 'brainwashing consists basically in isolating a human being, keep them out of contact, putting him under long stress in relationship to interviewing and interrogation ... without having to resort to any esoteric means' (McCoy, 2005, p. 220).

Transformations in the types of building used by Dr. Cameron, and in the buildings themselves, reflect the search for increasingly protracted and abusive forms of internment - an architectural drive that brought the psychiatrist's 'laboratories' closer to prisons and military facilities. As we will propose below through a discussion of the Kubark manual, the scientific community working in and reflecting on Dr. Cameron's 
laboratories developed some sort of conceptual framework in their search for 'mind control' and their vague suspicions of Soviet 'brain washing'. For McCoy, the publications were too elusive and cryptic to be considered science, and he settles the matter by recourse to the researchers and collaborators themselves: doubts began to be voiced about the scientific character of the Soviet experiments which had once appeared so disturbing. A 1956 report by Lawrence Hinkle and Harold Wolf of the Cornell Medical Center at the New York University had already expressed misgivings about the once-fearsome idea of 'brainwashing'. The report concluded that the Bolsheviks were merely replicating old practices of the Tzarist secret police, which included using 'isolation, anxiety, lack of sleep, uncomfortable temperatures and chronic hunger' (McCoy, 2005, p. 218). Other techniques included forcing people to stand up for hours. The authors saw nothing in them that might differ radically from older forms of torture. In the case of Chinese and Korean torturers, new technologies were simply added to their own pre-existing repertoires, including more 'traditional' tools like shackles and chains.

An analysis of the technology of these 'modern methods' of 'scientific' torture would agree with these conclusions, reminding us of Bruno Latour's (2013) warnings against attempts to 'purify' and separate practices which are in fact hybrid and create opposing fields: the traditional and the new. Behind this false dichotomy - like that of 'psychological versus physical' torture - lay torture plain and simple with 'modern' methods added to 'artisanal' repertoires. From the very beginning of the 'technological race' for mind control inside Nazi camps, Gestapo officers had been using 'protracted isolation, beatings and humiliation' (McCoy, 2005, p. 215), long before Kurt Plotner's Dachau experiments. Even with funding for research and the use of camp infrastructure, the SS never abandoned the physical abuse of prisoners (McCoy, 2005).

While based on a false dichotomy, underscoring the differences between more archaic forms of torture and subtler or more 'scientific' ones did, however, seem to serve the purpose of concealing these practices from public scrutiny. In response to accusations of torture during the Algerian war, the French government published the Wuillaume report, which justified French techniques by appealing to similar distinctions. Wuillaume claimed that the methods developed by the French Army

'water and electricity whenever used carefully seem to produce a shock which is more psychological than physical and therefore do not constitute excessive cruelty ... according to some medical opinions, the method of the water pipe does not involve risks for the victim's health' (McCoy, 2005, p. 215).

\section{Scientism as strategy}

Both McCoy's (2005) and Klein's (2008) denunciations of the CIA programs frame scientism as an equally useful strategy of distraction in the USA. During the 1970 and 1980 , Congressional Hearings probed accusations that the US was supporting or teaching torture in Latin America and investigated the brutal psychiatric methods used at McGill. In the first case, the CIA's strategy was always to assert that the Agency was in fact teaching milder, more humane methods of interrogation, as opposed to more brutal, less refined ones. In May of 1971, the US Senate Foreign Relations Committee heard the Chief US Office of Public Safety adviser for Brazil, Theodore D. Brown. McCoy argues that, at these hearings, attempts to get to the bottom of the CIA's involvement in developing methods of torture were frustrated by the false dichotomy of psychological versus physical methods. Addressing Brown, Senator Clairborne Pell (D-RI), for example, claimed that:

'But from a police viewpoint, you would agree that psychological nonphysical methods of interrogation can be just as effective as the physical' (McCoy, 2005, p. 227). 
Regarding accusations of the CIA's involvement in 'psychological' torture experiments, Klein contends that, in the face of public opinion and Congressional pressure, the Agency adopted a double strategy: on the one hand, agents insisted on the official version, i.e., that the experiments were aimed exclusively at strengthening the psychological strength of US personnel in the event that they are captured by the enemy; on the other, after 'psychological torture' had become completely discredited, the Agency hid the old experiments behind a veneer of ridicule. The idea that agents in the 196os were using LSD in collaboration with 'mad scientists' sounded more like an espionage pantomime than a real threat. Again, in Latourian terms (1999), by then ideas such as 'brainwashing' had gone from modern 'scientific truth' to dated 'belief'. As Klein reminds us, 'in the end the word torture was never used' (Klein, 2008, p. 38).

Yet the hearings did have some practical effects. In 1975, Congress again investigated the Public Safety Program being run in Brazil. Senator Abourezk this time found 'widespread allegations that the program was training torturers within the Latin American police' (McCoy, 2005, p. 227). Congress cut all funds and the Office of Public Safety was closed.

Judicially, Congressional probes came up against special protection given to key individuals, resulting in no sentences. But hearings and press exposés into the use of methods of psychological torture also encouraged 9 former patients of Dr. Cameron to file a suit against the CIA's funding of the latter's research into mind control and sensory deprivation. The CIA tried to dismiss the motion in 1988, which a Federal Judge rejected, and the Agency was forced to pay 750,000 dollars in reparations (McCoy, 2005, p. 220).

The hearings also revealed just what the CIA was prepared to admit in public concerning its role in sponsoring practices that straddle the fine (and somewhat artificial) line between psychological and physical torture. In 1988, the New York Times published the story of members of the Honduran armed forces trained in 'psychological interrogation' methods by the US. The agent described these methods as including:

'make him stand up, don't let him sleep, keep him naked and isolated, put rats and cockroaches in his cell, give him bad food, serve him dead animals, throw cold water on him, change the temperature' (McCoy, 2005, p. 234).

The report also featured torture victims' denunciations of the use of electroshocks. At the hearings of the US Senate's Select Committee on Intelligence, Deputy Director Mr. Stolz describes the practices taught as milder:

'we are talking about ... sitting in a chair on a stool for a long period of time, some sensory deprivations, sounds..." Senator Bradley: Changed the temperature?

Mr Stolz: I don't know the answer to that. That's not impossible" (McCoy, 2005, p. 235).

\section{The Kubark manual}

The chilling declarations of the use of 'interrogation methods' in Honduras suggest a region-wide application of severe techniques that verge on, or in fact constitute, torture. Another effect of these hearings was that certain documents emerged from them, including formalized versions of bodies of knowledge about torture. Despite initially refusing, the CIA was eventually forced to disclose a handbook called the Kubark Counterintelligence Interrogation. The Kubark was a manual edited for internal use in 1963, intended for training and practical purposes. 
Does the Kubark claim for itself the category of 'scientific'? Does it consider interrogation a science? Not in principle. The primary aim of the Kubark manual is to aid the interrogator in carrying out a practice which is described as a 'craft': 'It consists of no more than obtaining the needed information through responses to questions. As is true of all craftsmen, some interrogators are more able than others' (Unknown, 1963, p. 1).

But its author also wants to help interrogators become acquainted with important contributions to the field deriving from 'extensive research, including scientific inquiries conducted by specialists in closely related subjects' (Unknown, 1963, p. 1), and from the 'scientific findings of 'pertinent, modern knowledge' (Unknown, 1963, p. 2). Referring specifically to psychology, the author clarifies that while 'American psychologists have devoted more attention to Communist interrogation techniques, particularly "Brainwashing" (Unknown, 1963, p. 2), other important developments have emerged relating to

"the effects of debility and isolation, the polygraph, reactions to pain and fear, etc., etc. So that 'It is no longer possible to discuss interrogation significantly without reference to the psychological research conducted in the past decade'. (Unknown, 1963, p. 2)

The author recognizes that:

'While psychologists have sought for methods of imposing controls or alterations from the outside, the Communists would have developed 'the creation of internal controls - i.e. - conversion of the source, so that voluntary cooperation results.' (Unknown, 1963, p. 2).

Achieving control over the interrogatee, the ultimate aim of a good interrogator, means acquiring the 'capacity to generate, alter, or halt human behavior by implying, citing, or using physical or psychological means to ensure compliance with direction. The compliance may be voluntary or involuntary' (Unknown, 1963, p. 4).

This compliance should ideally be voluntary, or appear as such to the interrogatee. In characterizing this relationship, the manual suggests at several points that the interrogatee should come to look upon their interrogator as a form of authority, namely as a father figure. The desired effect is to induce regression on interrogatees, leaving them defenseless, in a child-like state of mind where they are more likely to obey and comply. Despite the author's lip-service to 'the Communist frame of reference' (Unknown, 1963, p. 2), the concept of control undoubtedly refers us to the CIA's own programs on mind control, and regression stands out as the main contribution of Dr. Hebb and Dr. Cameron to the conceptual toolbox of interrogation, as prescribed by the Kubark manual.

But the Kubark manual also relies heavily on a third category, that of the 'environment', which brings buildings, the locales of interrogation, to the foreground. If used skillfully, the 'environment' can relieve the interrogators of some of their hard work, making the interrogatee "defeat himself" (Unknown, 1963, p. 52). If the interrogatee is detained, "the interrogator monopolizes the social environment of the source" (Unknown, 1963, p. 3) through the artful manipulation of the environment:

'He exercises the power of an all-powerful parent, determining when the source will be sent to bed, when and what he will eat, whether he will be rewarded for good behavior or punished for being bad. The interrogator can and does make the subject's world not only unlike the world he had been accustomed to but also strange in itself.' (Unknown, 1963, p. 53)

The importance of the 'environment' is such that it affects the very core of the relation between interrogator and interrogatee. Creating a fundamentally materialized relationship between them, the environment becomes and experiential and material substitute for the outside world. 
'The history of interrogation is full of confessions and other self-incriminations that were in essence the result of $a$ substitution of the interrogation world for the world outside. In other words, as the sights and sounds of an outside world fade away, its significance for the interrogatee tends to do likewise. That world is replaced by the interrogation room, its two occupants and the relationship between them' (Unknown, 1963, p.57).

The interrogator's powers rely basically on the unequal character of this materialized relationship. Control is to be attained through an enhanced use of the basic relations inscribed in what we will describe below as 'reversed buildings' (sensu Markus, 1993). If detained, the interrogatee can affect neither the layout, furniture nor any matter inside the building, nor can they move freely within it. The interrogator, on the other hand, can use a series of techniques, all of which rely on how they can alter the interrogatee's environment. These include putting them in a cell with (1 or 2) informers, making them think that others are informing on them by 'whisking the witness past their door or cell' (Unknown, 1963, p. 68), etc. Though classed by the manual as non-coercive, and indeed not even requiring that the interrogator lay a hand on the interrogatee, all these techniques situate control as a function of that primary asymmetry between both actors, thus placing the building at the center. In fact, the Kubark' $s$ framework ascribes such strong agentic powers to the building itself that it comes to stand in for a person. By modifying the environment, a single interrogator can even make the interrogatee feel as though they are dealing with two different people:

'An interrogator working alone can also use the Mutt-and-Jeff technique. After a number of tense and hostile sessions, the interrogatee is ushered into a different or refurnished room with comfortable furniture, cigarettes, etc. The interrogator invites him to sit down and explains his regret that the source's former stubbornness forced the interrogator to use such tactics. Now everything will be different' (Unknown, 1963, p. 73).

Still within the chapters on non-coercive techniques, the manual explores the connections between time and space for the purpose of regression:

'some interrogatees can be repressed by persistent manipulation of time, by retarding and advancing clocks and serving meals at odd times - ten minutes or ten hours after the last food was given. Day and night are jumbled. Interrogation sessions are similarly unpatterned (sic.) the subject may be brought back for more questioning just a few minutes after being dismissed for the night' (Unknown, 1963, p. 77)

The section on 'the coercive counterintelligence interrogation' (Unknown, 1963, p. 82) begins with a warning about the permits that might be necessary to carry out this type of interrogation. If bodily harm is to be inflicted; if medical, chemical, or electrical methods or materials are to be used ... if the detention is locally illegal... etc. (Unknown, 1963, p. 82). Section D. 'Detention' insists on isolating the subject, and develops the importance of clothes:

'If (...) arrangements have been made for the confinement of a resistant source, the circumstances of detention are arranged to enhance within the subject his feelings of being cut off from the known and the reassuring, and of being plunged into the strange. Usually his own clothes are immediately taken away, because familiar clothing reinforces identity and thus the capacity for resistance. (Prisons give close haircuts and issue prison garb for the same reason)' (Unknown, 1963, p. 86)

But nowhere is the importance of the skillful use of the environment as fully developed as in the section on the deprivation of sensory stimuli. The environment is here taken a step further, and the very rooms that detainees are made to inhabit become the direct instruments of control and regression:

'The chief effect of arrest and detention, and particularly of solitary confinement, is to deprive the subject of many or most of the sights, sounds, tastes, smells, and tactile sensations to which he has grown accustomed' (Unknown, 1963, p. 87) 
At this point, the works of psychologists begin to feature, including that of John C. Lilly on polar explorers and solitary sea-farers. This study established that

'The symptoms most commonly produced by isolation are superstition, intense love of any other living thing, perceiving inanimate objects as alive, hallucinations and delusions' (Unknown, 1963, p. 88).

The McGill university experiments are described in relation to sound deprivation and temperature changes, perhaps the most extreme cases of manipulating the environment. These are particularly relevant to Belo Horizonte, as we will see traces of how the 'environments' referred to in the manual were replicated at the DOPS police station.

'A number of experiments conducted at McGill University, the National Institute of Mental Health, and other sites have attempted to come as close as possible to the elimination of sensory stimuli, or to masking remaining stimuli, chiefly sounds, by a stronger but wholly monotonous overlay. The results of these experiments have little applicability to interrogation because the circumstances are dissimilar. Some of the findings point toward hypotheses that seem relevant to interrogation, but conditions like those of detention for purposes of counterintelligence interrogation have not been duplicated for experimentation' (Unknown, 1963, p. 88).

'At the National Institute of Mental Health two subjects were "...suspended with the body and all but the top of the head immersed in a tank containing slowly flowing water at $34.5 \mathrm{C}$. degrees (94.5 F degrees)..." Both subjects wore blackout masks, which covered the head, allowing for breathing but nothing else. The sound level was extremely low; the subject heard only his own breathing and faint sounds of water from the piping. Neither subject stayed in the tank longer than three hours. Both passed quickly from their normally willful thought to a state of tension resulting from an unsatisfied hunger for sensory stimuli and a concentration upon the few available sensations, to private reveries and fantasies and eventually to visual imagery somewhat resembling hallucinations' (Unknown, 1963, p. 88).

After reviewing other similar experiments, the author's conclusions again foreshadow some of the materializations found at the Belo Horizonte DOPS.

'These findings suggest - but by no means prove - the following theories about solitary confinement and isolation:

1. The more completely the place of confinement eliminates sensory stimuli, the more rapidly and deeply will the interrogatee be affected. Results produced only after weeks or months of imprisonment in an ordinary cell can be duplicated in hours or days in a cell which has no light (or weak artificial light which never varies), which is soundproofed, in which odours are eliminated, etc. An environment still more subject to control, such as a water-tank or iron lung, is even more effective' (Unknown, 1963, p. 90).

Perhaps the conclusion which best encapsulates the importance of sensory deprivation is number 4, which affirms the methods' suitability for causing the interrogatee to regress and turn against themselves:

'The deprivation of stimuli induces regression by depriving the subject's mind of contact with an outer world, and thus forcing it upon itself. At the same time, the calculated provision of stimuli during interrogation tends to make the regressed subject view the interrogator as a father-figure. The result, normally, is a strengthening of the subject's tendencies toward compliance' (Unknown, 1963, p. 90). 


\section{An archaeological study of the DOPS}

The architectural structure of the building which once housed the DOPS (Department of Political and Social Order) provides important insights into the context of repression and social control within which it operated during the dictatorship. Understanding the architectural structures of illegal detention centers such as the DOPS is a way of understanding the agency of an entire system, as well as its strategies of control and exercise of power. From an interpretive point of view, archaeologists have started to emphasize the role of objects and structures in the construction of social relations (Salerno and Zarankin in Myers \& Moshenska, 2011). By analyzing material culture, we can understand production, reproduction and changes in social relations within a society.

The dossier on the building (De Oliveira Souza \& Magni 2015) contains a map which can be read as an element in an architecturally conceived and materialized system. It allows us to interpret the rationality embodied in the spatial distribution of the police station's rooms. As described above, the police station was built at a time when police and military authorities were particularly concerned with 'modernizing' security and the armed forces. However, when we take a closer look at the connections the building itself sought to establish between space, power, knowledge and authority, its internal structure provides interesting insights into the older roots of this project of modernization. As Zarankin has explained in his (2002) synthesis of the possibilities of archaeological analysis of architecture, the layout of many modern buildings establishes a direct relationship between the depth of certain rooms and the relative position of power of those who use it. Following ideas put forth by Hillier and Hanson (1984), Zarankin explains that most of our contemporary houses have been designed to reinforce a particular relation of power between the generations, one that is associated with property. The bedrooms designed to be used by the older generation, usually the owners of the house, tend to occupy the deepest positions in the layout. They are either at the end of corridors or require us to cross one or more rooms to reach them. Depth of space, understood as that greater portion of space or number of rooms we are required to cross to reach a certain person's room, attests to that person's preeminent position within the domestic space. People at the head of a household tend to occupy its least accessible space, nestled in its deepest room. Keeping this connection between power and depth in mind, let us now turn to the map of the second floor of the police station and locate room number 1 , near the bottom left-hand corner.

Figure 1: Map of the second floor. (Source : De Oliveira Souza, Magni et al., 2015)

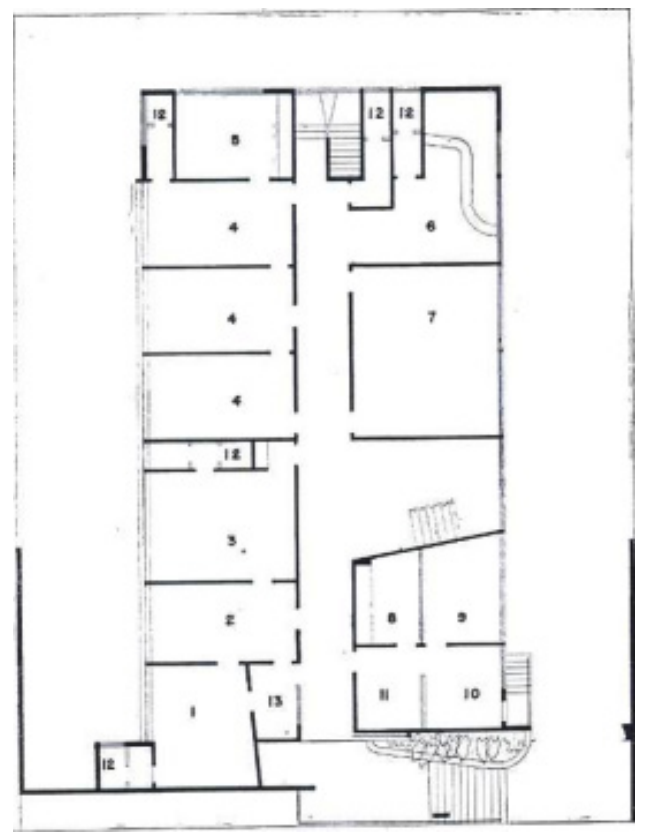


In the original map, this room is marked as the head police inspector's room; that is, it was the room designed for the person at the summit of the building's hierarchy. It is therefore no coincidence that, regardless of which staircase one used to reach this room, the corridor and at least one room would have to be crossed to access it. The room is buffered between rooms 1, allocated to 'sub-inspectors and investigators', and room 13, marked as a 'waiting room'. Room 13 provides a space for contention, an area for pause, requiring that we wait for the inspector to interrupt his tasks and grant us his time, reinforcing the order of his priorities and his importance within the hierarchic framework of power and authority inscribed in the building. Having explored the links between authority and depth of space, and before moving on to the lower floors, let us note that room number 9 on the map also occupies quite a deep position, but it is one which is more connected to permanence than power. Room number 9 was marked on the original map as being an extra storeroom, occasionally used by police officers or civil servants who, for whatever reason, had to spend the night at the police station. If the connection between depth and power is clear in the case of the head police inspector's room, depth would here be associated with intimacy and rest, anticipating the connection between relative space and stay.

Markus' (1993) and Hillier and Hanson's (1984) analysis of the space patterns in modern buildings have proven that certain types of buildings invert the connections between power and depth found in most households, where greater depth is allocated to the rooms of owners, heads of households, or those expected to exert greater power, as was the case with the head police inspector. These authors' studies have proven that inside prisons, hospitals and other 'inverted buildings', it is those people with the least power detainees and patients - who are allocated rooms in the deepest reaches. This is likewise the case in the first floor, the layout of which is also included in the dossier, and which was designed to house the cells.

Figure 2: Map of the first floor (Source: De Oliveira Souza, Magni et al., 2015)

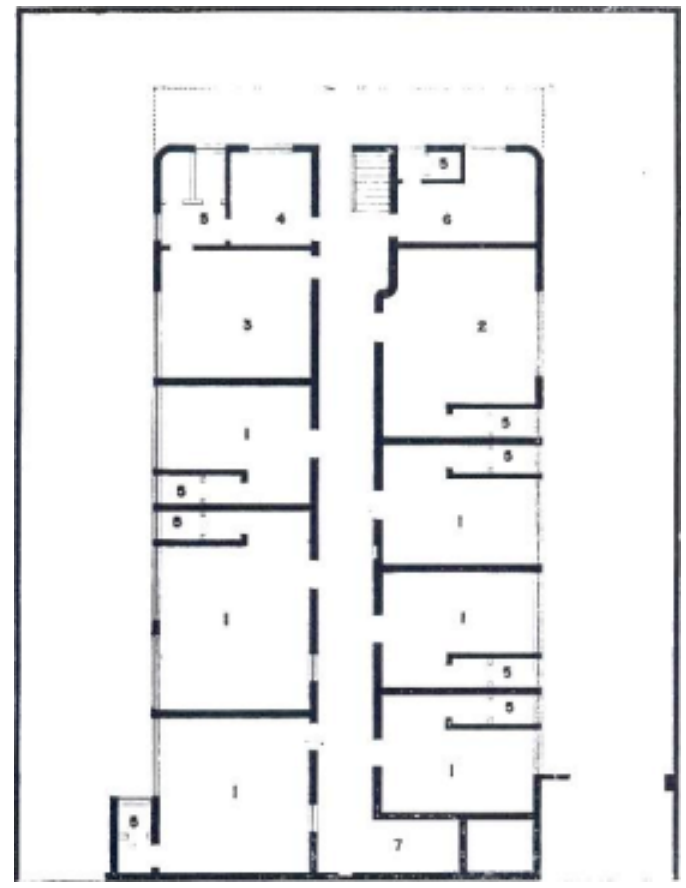


The first floor was accessed through the staircase at the top of the layout. This means that the spaces marked on the map as 3, 4, and 6, and referred to, respectively, as 'guard accomodation', 'guard commander' and 'storeroom', were more easily accessible rather than deeper. In contrast, the door to the room marked 2, the 'cell for women', is at a slightly greater depth than the previous spaces. All the other spaces, marked 1 on the original design, are the deepest: these are the cells. Floor 1 places those people with the least power that is, the prisoners - in the deepest places, exactly the opposite of what holds in the upper floors. Hillier and Hanson (1984) and Markus (1993) build on the work of Foucault (1975) to explain that such a distribution of power is directly related to the type of relations reinforced in modern prisons, hospitals, and, in this case, cell blocks: these were inverted buildings. A power-knowledge relation by which visitors are housed over long periods of time as patients and detainess, and where the power exerted over them - the power of doctors, interrogators, etc. - relies partly on the fact that such power-wielding specialists, as opposed to those interned, can move about the building. As with Dr. Cameron's experiments, doctors and interrogators can leave the building any time they want. Their task as modern specialists who are granted the privilege of moving about the building where others are interned, includes making critical assessments of the interns: whether they are guilty or innocent, whether they have been 'reformed' or cured, etc. Indeed, as the dossier points out, during the Brazilian dictatorship the Belo Horizonte DOPS was a gateway to other places of internment. It was here that the critical category of 'subversive' could be tagged onto the lives and bodies of the detainees. In the case of the Belo Horizonte DOPS, the ascription of this category was irreversibly mediated by the use of the 'environment'. It was arguably the same form of knowledge, situated at the crossroads between psychiatry and torture, which led Dr. Cameron of McGill University to make important structural changes to his laboratories, to militarize his objectives and audiences. It is the same form of knowledge which, encapsulated in the Kubark interrogator's manual, advised readers to make use of the building in ways which took the visitor-resident relationship a step further. In the next part of this article, we will examine the changes and adaptations that this form of knowledge brought to the building.

\section{Lived spaces of state violence}

Our analysis of the building has thus far consisted of evaluating how its spatial layout reflected projected relations such as hierarchy and assessments. These relations, inscribed in the DOPS building built in 1958, merely confirm that, as with so many other buildings in South America, the architecture of the DOPS police station was 'modernized' to suit larger projects of restructuring. The fact that the DOPS building in Belo Horizonte was an integral part of large-scale efforts to 'modernize' the police would thus appear to fit the somewhat apolitical narrative of modernization as development, wherein technology - in this case the state tool of policing - acts to better manage the body politic. In terms of this relation of modern management, space, as described in the police station plans, appears to 'speak for itself'.

However, the Kubark manual provides an important source that is contemporary to the Brazilian dictatorship - a backdrop against which to test the impact of so-called 'scientific torture' as developed by the US at the time. If proponents of Historical Archaeology recommend cross-examining material culture and spatial relations with emerging and contemporary bodies of knowledge (Funari, Hall and Jones, 1999), the Kubark manual provides evidence of a body of knowledge which incorporated the teachings of 'modern psychology and practice' to the 'art' of interrogation. The manual attests to the materialization of such practices and constitutes an important supplement to our reading of materialized spatial relations.

But evidence that such practices - or indeed chillingly similar ones - were being developed inside the DOPS only emerges when we complement our spatial analysis with the experiences of surviors of torture perpetrated at the DOPS. This final element in the construction of our spatial analysis highlights the 
usefulness of the work of Pamela Colombo $(2016,2017)$. The Argentinean anthropologist has drawn on the theoretical tools of critical geography (Masey, 1994; Harvey, 2006) to propose a notion of space that goes beyond its actualization as mere design and subsequent materialization. Colombo argues that, beyond analyses that conceive of space as being first devised and then materialized, a critical notion of space ought to draw at least as much on the experience of those who, despite having had little or no participation in its design, bear the knowledge of having experienced its effects. In this way, we complete the full cycle of buildings marked by state violence. In the case of survivors testifying about spaces of state terror, this has led Colombo to address the sometimes dazzling descriptions of survivors' surreal and painful experiences of repression in the Argentinian province of Tucumán.

In Belo Horizonte, the seemingly aseptic modern relations inscribed in the plans of the police station are given a cruel turn when we review the information about the police station's spatial outline and material culture. The evidence that emerges from photographs taken inside the building, woven together with testimonies of experiences of torture, allow us to make a connection with the body of knowledge committed to writing in the Kubark manual. It is through this testimonial and photographic evidence that we can reconstruct the entire cycle of the police station's design, construction, uses and abuses. The experience of victims and survivors is key to our construction of the DOPS as a place of state violence.

\section{Marks of torture}

In order to 'satisfactorily' function as a center of torture, the structure of the police station building underwent several adaptations. These adaptations were registered by the Truth Commission. Combined with testimonies, they provide uncanny evidence of the use of torture methods very similar to those developed by the CIA across the entire continent of the Americas, and prescribed by the Kubark manual in its successive editions.

The first adaptation was a full layer of agglomerated cork covering all the walls of a room, as highlighted in figure 3 .

Figure 3: Sound-proofed room with agglomerated cork walls (Source: authors' own photographs, 2018)

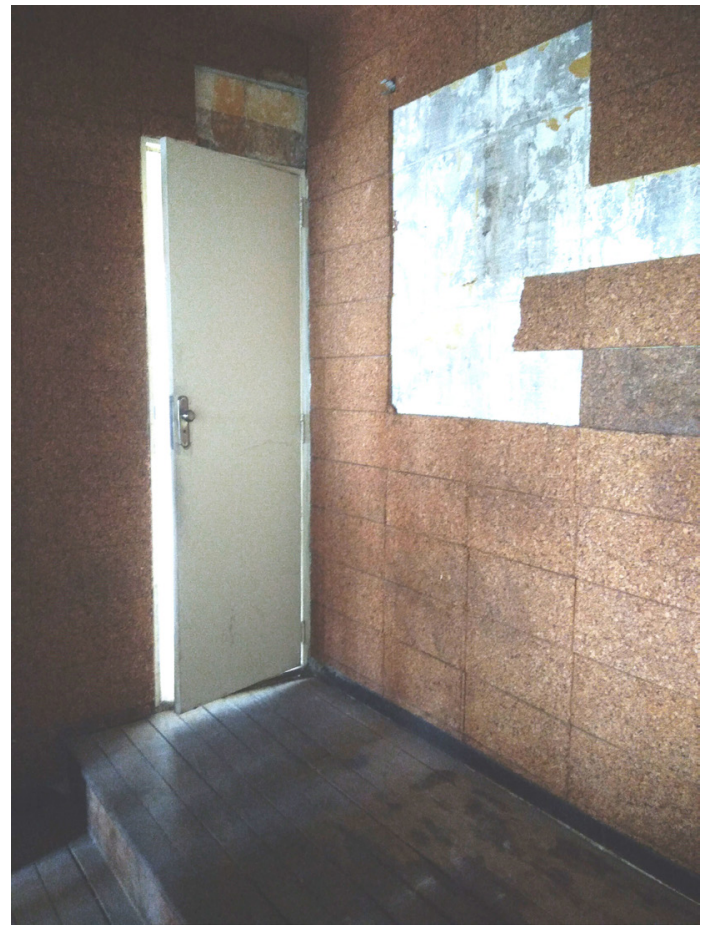


Photographs of this room, which is presently used as a cellar, show that it had a thick layer of this insulating material covering all four walls and the ceiling, making it completely sound-proof. The room, which does not appear in the original architectural plan, is located where the first plan situates the toilet, and is therefore accessible to non-staff only through the head police inspector's room. The only other route of access to this room is a staircase connecting it to the cell-block. Its position, deep in one of the most inaccessible rooms on the second floor, yet accessible from the cell-block, would correspond to the position of the detainee, who is shielded from the outside through as many as three rooms to the nearest staircase open to outsiders. This allows it to be accessed away from prying eyes, but under the intimidating supervision of the inspector.

Floors 2, 3 and 4 are connected by the staircase depicted on the right-hand side of the plans. Underneath the first flight of this staircase, absent from the original plans, is 'a small cupboard of some $80 \mathrm{~cm}$. length, $1.50 \mathrm{~m}$. height and $50 \mathrm{~cm}$. depth' (De Oliveira Souza, Magni et al, 2015, p. 83). The dossier records the testimony of Mrs. Emely Vieira Salazar, whose experience we will convey below, who testifies that she was hidden inside this place. In september 2013, Emely describes 'having been locked over a long period of time, after being tortured' (De Oliveira Souza, Magni et al. 2015, p. 83). The dossier points out the presence of several other similar cupboards underneath this staircase, and other unspecified places.

Testifying before the Minas Gerais State Commission for the Reparation of Victims of Torture, a person who chose to identify only by the initials H.R.C. mentions the use of several torture techniques inflicted on him or her in the third floor of the building. This person described 'the third room to the left' (De Oliveira Souza, Magni et al, 2015, p. 33) as having been one of the places he or she was tortured. The dossier also points out that victim H.R.C. was 'immediately tortured without any prior interrogation or identification' (De Oliveira Souza, Magni et al, 2015, p. 33), which provides further evidence of detention during the dicatorial regime. The authors of the dossier were also able to register the existence of a catwalk connecting the second floor to the yard next to the police station, a triangular patch containing a parking lot and a maintenance area.

Figure 4: Map showing the catwalk (passarela) connecting the police station to the building next to it, with a cell (cela) a 'swimming pool' ('piscina') and "sauna" (Source: De Oliveira Souza, Magni et al, 2015)

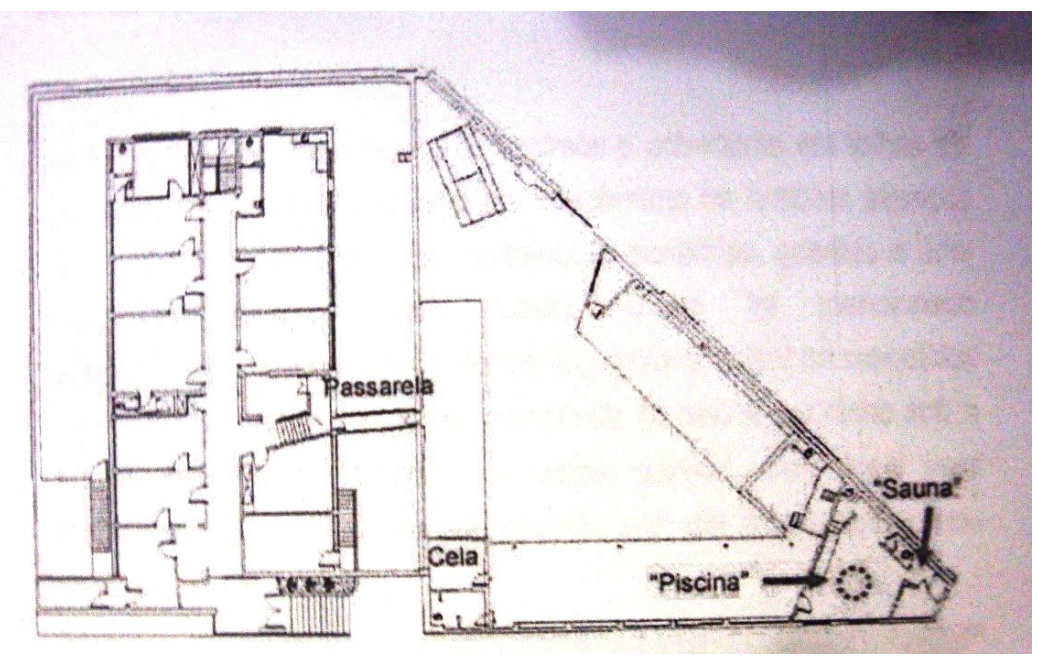


The catwalk, made of a long metal surface with metallic grids on both sides, accesses a structure containing another room, clearly identified as a torture chamber. Inside this building, two structures were identified. The first consists of a cavity excavated into the original floor, which, from the outside, reveals a circular hole of $1 \mathrm{~m}$. to $1.5 \mathrm{~m}$. in diameter. The cavity was later covered with white tiles, and the difference in materials from those of the floor, as well as their irregular cut, clearly indicates that this modification occured after the original floor had been laid. Later, when the police station was no longer operating as the DOPS, the cavity was covered in cement, but the authors of the dossier calculate that the hole is deep enough to fit an adult. The dossier describes this hole as a 'swimming tank', a term taken from a police officer who chose to remain anonymous. The term is a clue as to the 'tank's' true purpose, contrasting with what was usually described to visitors - that it had recreational uses. Next to this cavity is a 'cubicle' large enough to fit several people standing upright. The same police officer described this place as a 'sauna'. The entire assemblage was identified as a structure that enabled the 'hot and cold torture' that would result from alternating temperatures.

Figure 5: Photograph of the area where the torture described by an unidentified policeman as "hot and cold" was allegedly perpetrated. On the floor is the concrete filling covering the "swimming pool" (piscina) and in the background is the "sauna" room (Source: authors' own photographs, 2018)

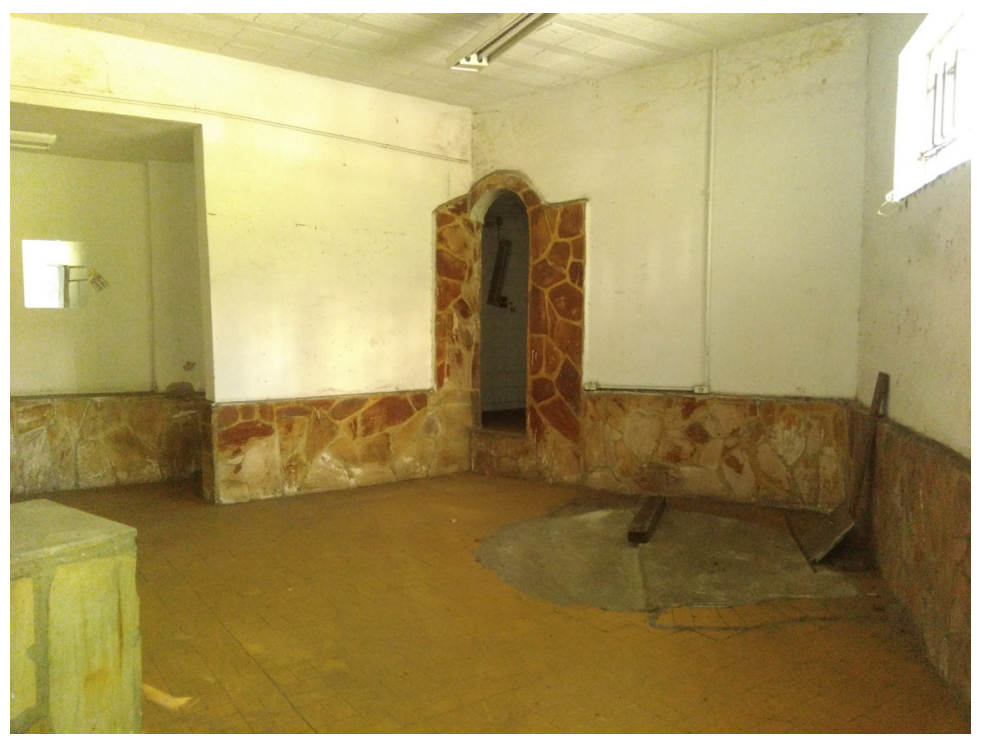

The material experiences of survivors inside the space of the police station provided the authors of the dossier with the information necessary to confirm the dictatorship's use of torture. But the level of detail in which victims described their experience of the police station's space and material culture can also shed light on the allegedly scientific character of the type of torture that they suffered at the hands of the Minas Gerais state authorities. In particular, their experiences confirm one of the themes stressed above, concerning the development of 'scientific torture' and sensory deprivation: its subtlety. The three testimonies gathered in the dossier describe the use of the 'reversed building' structure of the police station, which combined the more traditional function of classifying individuals considered 'critical' with innovations that include the swift use of torture apparel and extreme isolation.

The first testimony collected in the dossier was that of Mrs. Emely de Oliveira, then a psychology student and member of the organization Ação Católica Brasileira. During the dictatorship, this Catholic organization collected donations and personally assisted opponents of the military regime. 
Emely sometimes provided refuge in her own house or in those of friends and relatives. Her account describes the strategic use of space inside the DOPS at the time of her internment: detainees were divided by gender into separate floors:

'the women were locked inside rooms located on the second floor of the DOPS, while men were incarcerated in the prison cells of the first floor' (De Oliveira Souza, Magni et al, 2015, p. 29).

Emely also characterized the more sophisticated use of torture apparel in terms of subtlety. In Emely's experience, torture took place at night. It was then that portable material culture used to come into action: electric shock machines, and the dreaded pau-de-arara were quickly mounted for nights of torment only to be quickly dismantled the next morning to recreate an atmosphere of daily normality. This was, in Emely's view, one of the technical issues that these techniques aimed to 'solve'.

Figure 6: Painter Jean-Baptiste Debret portrayed several scenes of life in nineteenth-century Brazil, including this (1835) depiction of Overseers punishing negroes, where the man in the foreground is tied to a pau-de-arara ('parrot's perch'). As described by Emely, twentieth century pau-de-araras were mounted horizontally onto two chairs or tables, leaving the victim suspended in the air.

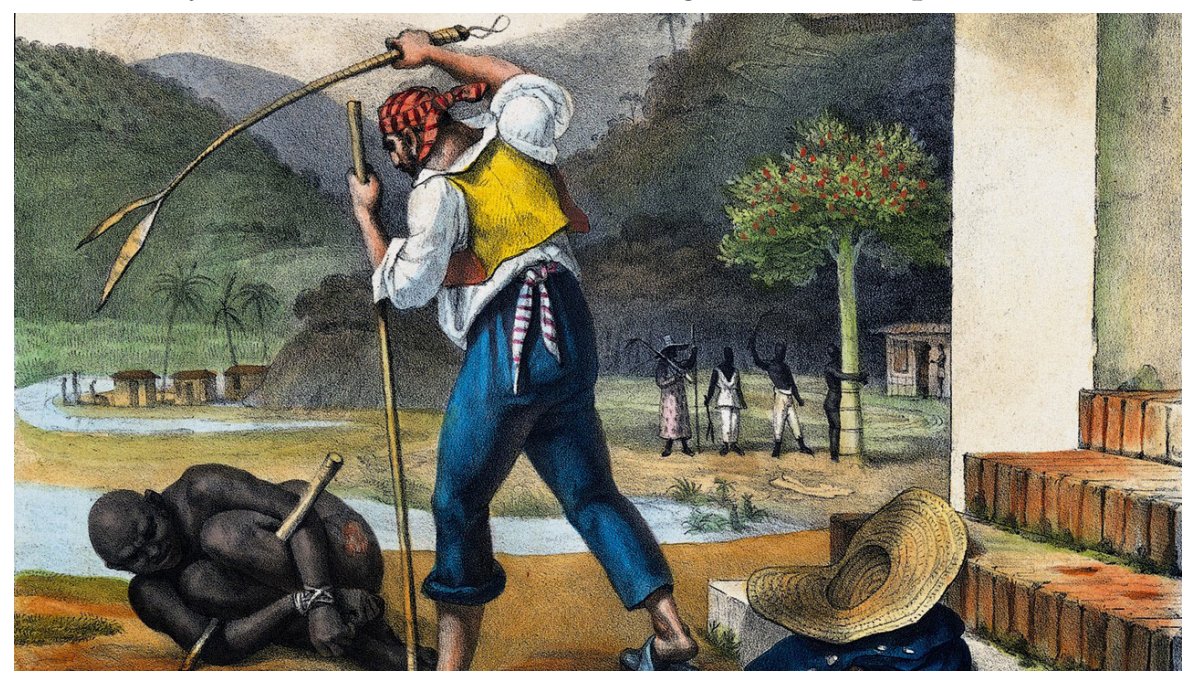

To illustrate these objectives, Emely reminds her interviewers of the time she remained incomunicando inside a small cupboard below the staircase. The cupboard-turned-cell not only kept her isolated but also served to create an appearance of normality in the eyes of an investigative commission attempting to make the Minas Gerais forces accountable for their actions.

'A commission went there. And they (the people in charge of the DOPS) showed them the entire DOPS, and they said that there was no one there, and that there was no torture, you see...Because torture consisted basically of electro-shocks with the machine, for which they would take people into a room at the back, and as for the pau-de-arara... they used to set it up then in there. They used to put a stick up on a chair and set up the pau-de-arara and put us there' (De Oliveira Souza, Magni et al, 2015, p. 29).

In Emely's account the only sophisticated technical element about these practices was that, operating around portable material culture, they fulfilled the main objective of obscuring the use of torture. Emely's own body, evidence of these practices, was thus hidden from the members of the commission. 
'I had been hurt badly from being tortured, and this eye here had gone all red. They tied me up and put me like that... under the staircase were they keep the brushes, that kind of thing. They opened that place and put me in there, and I was stuck in there for I don't know how long. Only later did I find out what had happened that day: they'd opened the DOPS to prove to everyone that they weren't keeping anyone in there, that there was no torture and there was nothing there, you see? And there I was, tied up under there' (De Oliveira Souza, Magni et al, 2015, p. 29).

Figure 7: The wardrobe inside the police station where E. was hidden from a commission supervising the police station in search of traces of torture (Source: De Oliveira Souza, Magni et al, 2015)
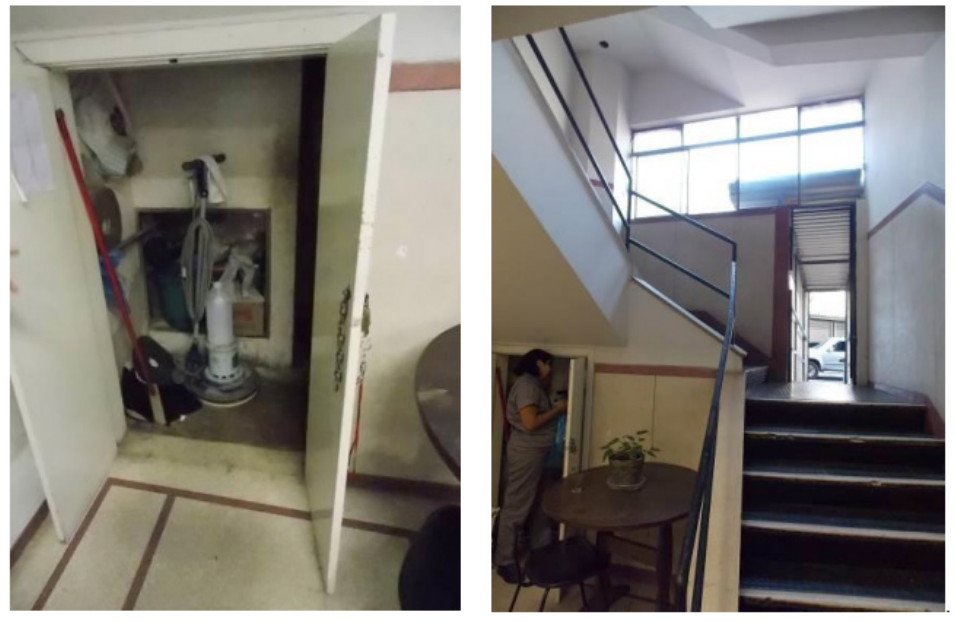

The second survivor interviewed in the dossier, identified by the initials H.R.C., was tortured in a room next to the "head inspector's room", and also describes having been subjected to methods which were a mixture of those leaving clearer marks on the body - electroshocks, pau-de-arara, beatings - with more discreet ones:

'At a certain time Lieutenant Melo sprayed something on me that made your flesh burn inside, without leaving traces on your skin. It must be an American product, I never found out what it was' (De Oliveira Souza, Magni et al, 2015, p. 33).

The third testimony collected in the dossier is that of Tim Garrocho, a rural worker and unionist from the nearby town Teófilo Otoni. Garrocho was detained in 1970 and told his experiences to his son, who wrote a book about the episodes of torture experienced by his father. References to a particularly interesting passage were included in the dossier:

According to Tim Garrocho there was a small room inside the DOPS building, a small cubicle, all coarse inside. A very thick and pointy coarse mortar. Before being thrown into that dungeon to be tortured, prisoners were flashed very strong lights in their eyes; and they would take off their clothes and leave them naked. The prisoner could not see anything, and it was dark everywhere. After a few minutes the prisoner would begin to notice that there was something strange inside that dungeon and, to their despair, it was lots of snakes. As they tried to avoid the snakes, and because they were naked, their whole body was hurt by the spiky points of the dungeon' (De Oliveira Souza, Magni et al, 2015, p. 39).

Garrocho's experience is very similar to accounts from in Central America in the 1980s. As is Emely's denunciation of what the Kubark called the "Mutt-and-Jeff technique". Head inspectors sometimes used to "offer a shower and better food, saying she needed to "relax" (De Oliveira Souza, Magni et al, 2015, p. 28). Yet Emely remained very far from 'compliance'. On offering her testimony for the dossier, she even put forth her own understanding of psychological torture. 
'About psychological torture, for example, I had a 5-year-old niece who was in kindergarden. They used to say: "we're going to get your niece, your sister, your mother." They used to threaten me, and they knew all about me and my family. So it's a truly horrible thing, because you never knew what was going to happen, you never know what will become of these threats' (De Oliveira Souza, Magni, et al, 2015, p. 28).

Emely's own theory of psychological torture is fascinating, not only because she was herself a psychology student at the time, but also for what it tells us about relationships defined by and in the very building where internment took place. Anchored in the inmate's point of view, Emely's theory refers to the basic opposition between her situation and that of her torturers. Held captive, there was nothing she could do for her family. Her torturers' conduct inside the building, in contrast, had caused her to believe they were capable of anything. Much could be said about her courage and clear-mind during these moments of agony. But with respect to 'scientific torture', her fears definitey combined a basic (some might say premodern) sense of helplessness, compounded with a heightened sense of unlimited knowledge and means in the hands of her captors. This enhanced sense of helplessness was the ultimate aim of experiments in 'mind control'.

In retrospect, and in the light of similar technological efforts elsewhere, the practices confirmed by Emely's experience and that of the other survivors reveal the hybrid character of practices hidden behind the façade of 'psychological' or 'scientific' torture. They confirm and materialize the dichotomy of 'modern' vs 'old' torture techniques. A false dichotomy, where sensory deprivation was combined with the pau de arara, which dates back to Brazilian slavery. Where sound-proofed rooms and water tanks were fitted into a building that became infamous for its nightly beatings. And where interrogators overstimulated detainees' eyesight only to have them immediately thrown into what one of them described as a "dungeon" filled with snakes.

Since they left less visible marks on the buildings and bodies where they took place, the tortures denounced by detainees were more effective. They relied on portability and the fact that torture devices could be hidden. The torture techniques suffered by Emely, H.R.C. and Tim Garrocho could be used while official discourse denied their very existence or downplayed their importance. It must be remembered that, as Martins Filho's (2017) book and the work of other historians have shown, pressure from national and international organizations denouncing torture was key at several moments in the course of the regime's history. In the face of such denunciations, being able to state that more refined interrogation methods were being used, without asserting nor denying that these were in fact torture techniques, must have been very useful to the regime. The use of the material culture of 'scientific torture' enabled the same obscurity.

Received: October 16, 2017

Approved: March 05, 2018

Revision: Luiz Costa

\section{Acknowledgements}

We would like to thank PhD candidate Juliana Brandão of the Federal University of Minas Gerais (UFMG) and Cristina Mendanha, for their help with access to the dossier, which saved us hours of archival searches. 


\section{References}

COLOMBO, P. 2016. "Espacios de desaparición: cuando la teoría crítica del espacio ayuda a pensar la violencia." In: Estudios para la no-violencia 2: pensar las espacialidades, el daño y el testimonio. Puebla, México: Afínita Editorial. pp. 147-163. . 2017. Espacios de desaparición. Vivir e imaginar los lugares de la violencia estatal. Tucumán, 1975-1983. Buenos Aires: Miño y Dávila.

COMISSÃO NACIONAL DA VERDADE. (2014) Relatório Final. Brasilia. Brasil. online version http://cnv. memoriasreveladas.gov.br/index.php/outros-destaques/574-conheca-e-acesse-o-relatorio-final-da-cnv COSTA, D. 2017. O Passado que ninguém quer Lembrar: Uma Arqueologia dos Espaços de Repressão em Belo Horizonte. Monografia (conclusão de curso). Belo Horizonte: Universidade Federal de Minas Gerais, Faculdade de Filosofia e Ciências Humanas.

DE OLIVEIRA SOUZA, F.; MAGNI, T.; DE SOUZA MARQUES, R.; DOLABELA CANFORA, A.; BATISTA FIORAVANTE, B.; HENRIQUE RANGEL, C.; DIAS MURTA, C.; ROCHA SILVA, D.R.C.; LIMA DE SÁ FORTES, R.; FERREIRA RUBEM, G.; MOREIRA DALFIOR, T.M.; GRZYBOWSKI, Z.; PERILO, M.C.; MAIA, L.D.; DE ALMEIDA, J.R.; COSTA, M.; FAJARDO DE OLIVEIRA, D.; MELLO GRZYBOWSKI, A.C 2015. Dossiê de Tombamento do Edifício da Antiga Sede do DOPS de Minas Gerais. Belo Horizonte: IEPHA-MG.

FOUCAULT, M. 1975. Discipline and Punish: Birth of the Prison. New York: Random House.

FUNARI, P.; HALL, M. \& JONES, S. 1999. Historical Archaeology: Back From the Edge. Londres e Nova Iorque: Routledge.

GASPARI, E. 2009. As Ilusões Armadas. A Ditadura Escancarada. São Paulo: Companhia das Letras. GONZALEZ-RUIBAL, A. 2011. "The archaeology of francoist concentration camps (1936-1952)". In: MOSHENSKA, G. and MYERS, A. (eds.), Archaeologies of internment. London and New York: Springer. pp. 53-75.

HARVEY, D. 2006. “Space as a Key Word.” In: CASTREE, N. \& GREGORY. D. Castree (eds.), David Harvey: a critical reader. New York: Wiley Blackwell. pp. 315-335.

HILLIER, B. \& HANSON, J. 1984. The Social Logic of Space. Cambridge: Cambridge University Press.

KLEIN, N. 2008. A doutrina do choque. A ascensão do capitalismo de desastre. Tradução de Vania Cury. Rio de Janeiro: Nova Fronteira.

LATOUR, B. 1999. A esperança de Pandora. Bauru: EDUSC. . 2013. Jamais fomos modernos. 3a ed. São Paulo: Editora 34.

MARKUS, T. 1993. Buildings and Power. Freedom and Control in the Origins of Modern Building Types. Londres: Routledge.

MARTINS FILHO, J. 2008. "Tortura e ideologia: os militares." In: Desarquivando a ditadura. Memória e Justiça no Brasil. São Paulo: Aderaldo e Rothschild. pp. 179-203. . 2017. Segredos de Estado: O governo britânico e a tortura no Brasil (1969-1976). Curitiba: Prismas.

MASSEY, D. 1994. Space, place and gender. Minneapolis: University of Minnessotta Press.

MCCOY, A. 2005. “Cruel Science: CIA Torture and US Public Policy”. New England Journal of Public Policy, 19(2), article 15. pp. 209-254.

MYERS, M. \& MOSHENSKA, D. 2011. The Archaeology of Internment. Nova Iorque e Londres: Springer.

PATTO SÁ MOTTA, R. 2010. “Modernizando a repressão: a Usaid e a polícia brasileira”. Revista Brasilera de História, 30(59): 237-266.

UNKNOWN, 1963. Kubark. Unknown: CIA.

ZARANKIN, A. 2002. Paredes que Domesticam: Arqueologia da Arquitetura Escolar Capitalista. Campinas: IFCHUNICAMP. 
.; NIRO, C. 2008. "A materialização do sadismo: arqueologia da arquitetura dos Centros Clandestinos de Detenção da ditadura militar argentina (1976-83)." In: Arqueologia da repressão e a resistência na América Latina na era das ditaduras (décadas de 1960-1980). São Paulo: Annablume. pp. 183-210. ; SALERNO, M. 2011. "The Engineering of Genocide: An Archaeology of Dictatorship in Argentina" In: MOSHENSKA, G. and MYERS, A. (eds.), Archaeologies of internment. London and New York: 207-229.

\section{Pedro Fermín Maguire}

Federal University of Minas Gerais, Post graduate Program of Anthropology https://orcid.org/0000-0002-4739-7979

E-mail: pedritofmaguire@gmail.com

\section{Denise Neves Batista Costa}

Federal University of Minas Gerais, Post graduate Program of Anthropology https://orcid.org/000o-0002-3853-2286

E-mail: denisenbc@gmail.com 